\title{
Evaluating the Effect of Rumen Microorganisms in the Codigestion Process of Swine Manure and Rice Husk
}

\author{
Leite S. A. F., Leite B. S., Dell'Isola A. T. P., and d’Angelo J. V. H.
}

\begin{abstract}
Biomass from agricultural residues consists largely of cellulose, hemicellulose and lignin, which are responsible for forming a rigid structure with difficult biodegradation. A viable alternative to increase the release of these components and improve codigestion process is the fortification of the inoculum adding microorganisms from bovine rumen. The objective of this work was to evaluate the influence of inocula fortified with microorganisms from bovine rumen, either using ruminal content or bovine manure, on the codigestion of swine manure and rice husk. From the results of methane yield and specific methanogenic activity it was observed that the fortified inocula, improved the codigestion, especially during process startup. On a pilot scale, the use of bovine manure presented a relevant performance on methane yield. Considering the availability of bovine manure, it can be an interesting option to be used in the startup of codigestion of swine manure and lignocellulosic residues.
\end{abstract}

Index Terms-Agricultural residues, bovine rumen, inoculum, organic degrading bacteria.

\section{INTRODUCTION}

The need to reduce the consumption of fossil fuels and the emission of greenhouse effect gases has encouraged the use of renewable energy sources. Agricultural waste has a great potential for energy use. About 140 billion tons of agricultural waste are generated worldwide, which can be converted to produce energy equivalent to 50 billion tons of oil [1].

There is an increasing interest in the use of these residues for energetic purpose, among which biogas production stands out. Codigestion, which is the simultaneous anaerobic digestion of two or more substrates, has become an interesting alternative for the use of many different agricultural residues. Among some advantages, codigestion can improve the economic viability of the implantation of biodigesters and may contribute to increase biogas production. The proper selection of the co-substrates and their respective proportions allows a better nutrient balance, dilution of toxic substances, maintenance of an ideal $\mathrm{pH}$ and assures the moisture content required for the biodigestion and

Manuscript received February 15, 2019; revised July 12, 2019. This work was supported in part by the Universidade Federal de Viçosa (UFV), Fundação de Amparo à Pesquisa de Minas Gerais -FAPEMIG, Fundação de Amparo à Pesquisa do Estado de São Paulo (FAPESP) and Conselho Nacional de Desenvolvimento Científico e Tecnológico - CNPQ.

Leite S. A. F., Leite B. S. F., and Dell'Isola A. T. P. are with the Institute of Science and Technology, Universidade Federal de Viçosa (UFV- Campus Florestal), Florestal, MG, Brazil (e-mail: sibeleaugusta@ufv.br, brennoleite@ufv.br, atperet@ufv.br).

d'Angelo J. V. H. is with the Department of Chemical Systems Engineering, School of Chemical Engineering, University of Campinas, Campinas, SP, Brazil (e-mail: dangelo@ feq.unicamp.br). the reduction of ammonia concentration in the bioreactor [2].

Nowadays, codigestion processes have been investigated and improved to use lignocellulosic residues, such as agricultural residues composed by non-food elements (i.e. leaves, stem, bark and straw) [3]. Biomass from these agricultural residues consists largely of cellulose, hemicellulose and lignin, which are responsible for forming a rigid structure with difficult biodegradation [4]. It is known that one of the limitations regarding the codigestion of lignocellulosic materials is their recalcitrant character [3], [4].

A viable alternative to increase the release of cellulose, hemicellulose and lignin is the fortification of the inoculum adding microorganisms from the rumen [5]-[7]. Despite the recalcitrant nature of lignocellulosic biomass, it can be digested and used efficiently as a source of energy for ruminants [8]. These animals have suitable pre-stomachs for the fermentation process and the digestion of fibrous plants. They do not produce the enzymes necessary for the degradation of cellulose and other polysaccharides present in the cell wall of plants, however they allow the development of bacteria, protozoa, fungi and archaeas that perform this function [8]. The action of these microorganisms produces short chain fatty acids, predominantly from cellulose and hemicellulose which are essential for the metabolism of ruminants [9].

Wall et al. [6] used microorganisms from the ruminal content for biodigestion of grass silage and observed improvements in the continuous pilot scale process. However, they have not observed a significant difference in fortification of the inocula, in batch tests using laboratory scale. Lima et al. [5] used an inoculum from UASB (Upflow Anaerobic Sludge Blanket) reactors fortified with bovine manure or ruminal fluid, in the biodigestion of cane bagasse. In their work, the best methane generation results were obtained for fortified inoculum with bovine manure, followed by fortified inoculum with ruminal fluid. According to the authors, the best results using bovine manure can be explained due to the modification of the microbiota and also due to the increase of nitrogen in the biodigestion system, improving carbon/nitrogen ratio.

The presence of the microorganisms: Enterobacter, Bifidobacterium thermacidophilum and Caloramator, in an inoculum produced from bovine manure and used for food residues biodigestion, showed that they were responsible for the fast production of ethanol and butyrate (products of hydrolysis of food residues) and, consequently, the production of methane [7]. There are currently many studies that investigated the fortification of the inoculum with microorganisms from the rumen, especially when used in the biodigestion of lignocellulosic substrate [5]-[7], [10], [11] 
However, a study that uses this technique involving a codigestion of swine manure with lignocellulosic substrate was not found in the open literature. The physiological difference between pigs and ruminants leads to a differentiated diet and, consequently, the microbial community and the chemical composition of the excrements of these two species are different [12]. In this way, it is expected that the inoculation of microorganisms from the rumen, either by the direct addition of the rumen content or by manure addition, may improve the codigestion of swine manure and lignocellulosic residues, increasing methane production.

The objective of this work is to evaluate the influence of three different inocula prepared with microorganisms from bovine rumen on the codigestion of swine manure and rice husk. The efficiency of the inocula over the codigestion process will be evaluated considering the following parameters: total volume of biomethane production capacity in the biodigester; specific volume (calculated in terms of the concentration of volatile solids added) and specific methanogenic activity (SMA). The results obtained in the laboratory scale were used as reference for a test in a pilot plant with two biodigesters with a nominal capacity for 8 liters and batch feeding, which were evaluated as a function of methane generation as well.

\section{MATERIALS AND MethodS}

\section{A. Sampling}

Swine manure (SM) was collected from the finishing stage at the swine breeding unit (lineage Agroceres) of University of Viçosa (UFV - Campus Florestal). Bovine rumen content (BR) and bovine manure (BM) were collected at the same university, at the cattle sector.

A pre-fistulated Nellore Bovine was used to sample the BR. The animals were fed normally, with corn silage, cane and cattle food and after two hours of feeding it was conducted to cattle crush respecting the animal welfare. After being placed in the cattle crush, the fistula was opened for the manual collection of a small sample of BR $(300 \mathrm{~g})$. Fresh manure (approximately $300 \mathrm{~g}$ of $\mathrm{BM}$ ) was collected in the site of the animal maintenance. The upper and lower parts of the BM were discarded and the inner part used for inoculation. Once collected, the samples of BR and BM were immediately directed to the biodigester to minimize aerobic conditions. The use of the fistulated animal for the collection of ruminal content was approved by the Committee on Ethics in the Use of Animals (CEUA / UFV), according to process 38/2017.

Samples of rice husk (RH) were also collected at UFV Campus Florestal, during a period of four months. They were pre-dried at $65{ }^{\circ} \mathrm{C}$ in an oven-dry for two days to eliminate the extrinsic moisture and to obtain samples in the same operating conditions and capable of being handled. Thereafter, they were cut in a knife mill (Marconi-MA280) to obtain fibers with a length between 0.5-1.0 mm. After that, they were stored for conducting physico-chemical analyses and biodigestion experiments.Submit your manuscript electronically for review.

\section{B. Experimental Biodigestion Set}

Biodigestion experiments were conducted in glass containers with a total capacity of $1200 \mathrm{~mL}$ with a lateral opening for gas sampling. They were used for the production of the inocula and for the codigestion test of SM and RH. The biodigesters were immersed in a thermostatic bath to maintain the working temperature around $39{ }^{\circ} \mathrm{C}$ and they were operated without agitation. All tests were performed in duplicate.

The biogas was collected from the side of the flask and sent to a washer bottle with sodium hydroxide solution (NaOH: $3 \mathrm{~mol} \mathrm{~L}^{-1}$ ) to capture carbon dioxide and hydrogen sulfide. The purified gas was then directed to a graduated cylinder to measure the volume of methane produced by the volume displacement method. The volume of gas collected in the experiment was converted to volume under the Standard Conditions of Temperature and Pressure (STP).

\section{Inocula Preparation}

A biodigestion experiment was conducted in order to produce three inocula. The control inoculum was produced only with swine manure (ISM) and two inocula were produced fortifying SM with ruminal content (IBR) and bovine manure (IBM). For the production of the inoculum ISM biodigestion was performed with $600 \mathrm{~mL}$ of SM. To produce the IBR and IBM inocula, $500 \mathrm{~mL}$ of $\mathrm{SM}$ were mixed with BR and BM, using $150 \mathrm{~g}$ of each one. The experiments were carried out in batch mode and laboratory scale. The biodigestion process was conducted during 45 days or until methane generation was stabilized (i.e. daily production was less than $5 \%$ of the total volume), at $\mathrm{pH}$ between 6.0 and 7.5. For $\mathrm{pH}$ correction, it was used a sodium bicarbonate solution.

Some precautions related to this work and the inocula preparation were: the temperature of $39{ }^{\circ} \mathrm{C}$ to conduce the biodigestion process, which is considered the optimal temperature of bovine rumen functioning [8]. The manipulation of the rumen content and the bovine manure, to prepare the inocula, favored their minimum contact with the aerobic environment. It was observed that some studies used the ruminal liquid obtained from the rinsing and filtration of the ruminal content, which could lead to the loss of anaerobic microorganisms [6], [10]. Also, it was found researches that had used the liquid present in the rumen [13], [14]. However, it is estimated that about $75 \%$ of the ruminal microorganisms are adhered to the solid fraction (fibrous foods) and only $25 \%$ is found in the liquid fraction [8], [9]. Thus, in this work, it was chosen the directly and immediately addition of the ruminal (solid) content to the biodigester, in order to guarantee the fortification of the inocula and the reliability of the results.

\section{Codigestion}

A codigestion experiment for SM and RH was based on the Biomethane Potential (BMP) test and similar to the Specific Methanogenic Activity (SMA) [15], [16].

In this stage, the previously produced inocula (sludge) was used to digest the mixture of $600 \mathrm{~mL}$ of SM and $12 \mathrm{~g}$ of $\mathrm{RH}$ The amount of inoculum added was determined as a function of the concentration of volatile solids (VS) present in the 
sludge, respecting the constraint of 2 to $5 \mathrm{~g}$ of VS per biodigester. This procedure seeks to meet the conditions necessary for the SMA test [17]. Biodigestion and methane monitoring were performed until stabilization of methane generation. The configuration for the experiments is given in Table I. It must be highlighted that this configuration was performed in two consecutive moments (Test 1 and Test 2) and controls tests were performed only with the inocula produced.

TABLE I: PROPOSED CONFIGURATION FOR THE EXPERIMENTS TO EVALUATE THE USE OF INOCULA IN BIODIGESTERS

\begin{tabular}{ll}
\hline \hline Identification & Composition \\
\hline $\mathrm{BR}$ & Inoculum fortified with ruminal content (IBR) $+\mathrm{RH}+$ \\
& $\mathrm{SM}$ \\
$\mathrm{BM}$ & Inoculum fortified with bovine manure $(\mathrm{IBM})+\mathrm{RH}+$ \\
& $\mathrm{SM}$ \\
$\mathrm{SM}$ & Inoculum produced only with swine manure (ISM) $+\mathrm{RH}$ \\
& $+\mathrm{SM}$ \\
\hline \hline
\end{tabular}

where: $\mathrm{RH}=$ rice husk; $\mathrm{SM}=$ swine manure

\section{E. Biomethane Potential Assay-BMP}

Biomethane production capacity was evaluated as a function of the total volume of methane yield $\left(\mathrm{CH}_{4 \mathrm{tV}}-\mathrm{mL}\right)$ and the specific methane yield $\left(\mathrm{CH}_{4 \mathrm{spV}}\right)$, which is the volume of methane by mass of volatile solids added $\left(\mathrm{mL} \mathrm{CH}_{4} \mathrm{~g}^{-1}\right.$ $\mathrm{VS}_{\mathrm{ad}}$ ). The quantity of volatile solids added corresponds to the sum of the inoculum (IN), RH and SM contributions.

The result of the volume of methane produced was compared to the maximum theoretical value $\left(\mathrm{CH}_{4}\right.$ theo $)$, calculated from the sum of the contributions of RH and SM. In this case, it was considered that the RH has the capacity to produce $178 \mathrm{~mL}$ of methane per gram of VS added [18] and SM produces methane as a function of the amount of COD (Chemical Oxygen Demand ) added, as proposed by Chernicharo [19] according to Eq. 1:

$$
V_{C H_{4}}=C O D / f(t)
$$

where $V$ is the volume of methane (L); COD is expressed in $\mathrm{g}$ $\mathrm{L}^{-1}$ and $\mathrm{f}(\mathrm{t})$ is a correction factor for the operating temperature of the biodigester $\left(\mathrm{g} \mathrm{COD} \mathrm{L}^{-1}\right)$, that was calculated using Eq.2:

$$
f(t)=P \cdot K_{C O D} / R \cdot(273+T)
$$

where, $P$ is the atmospheric pressure $(1 \mathrm{~atm}), \mathrm{K}_{\mathrm{COD}}$ is the COD that corresponds to one mole of $\mathrm{CH}_{4}$, given by $64 \mathrm{~g}$ COD mol ${ }^{-1}, \mathrm{R}$ is the universal gas constant $(0.08206$ atm $\mathrm{L}$ $\mathrm{mol}^{-1} \mathrm{~K}^{-1}$ ) and $\mathrm{T}$ is the operational temperature of the biodigester $\left({ }^{\circ} \mathrm{C}\right)$.

The comparison between the theoretical values of methane yield and the measured ones gives the efficiency $(\mathrm{E})$ of the biodigesters (Eq. 3):

$$
E=\frac{\text { Acucumulated Measured Methane }}{\text { Theoretical Methane }} \cdot 100
$$

\section{F. Specific Methanogenic Activity (SMA)}

The maximum capacity of methane yield by the consortium of microorganisms present in the inoculum is known as Specific Methanogenic Activity (SMA) and it was evaluated following the methodology proposed by Chernicharo [19]. The volumetric production of methane was monitored daily and plotted. SMA was determined by obtaining the methane production rate from the angular coefficient of the section with the highest slope. Hence, the coefficient was given by the accumulated methane volume as a function of the incubation time $\left(\mathrm{mL} \mathrm{CH}_{4} \mathrm{~d}^{-1}\right)$. The obtained rate was then divided by the amount of initial biomass present in the biodigester (represented by the VS of the inoculum) and the SMA value was given as: $\mathrm{mL} \mathrm{CH}_{4} \mathrm{~g}^{-1} \mathrm{VS} \mathrm{d}^{-1}$. The volumetric production of methane was converted to COD $(\mathrm{g})$. Such conversion is possible by knowing the stoichiometric coefficient of methane oxidation, according to the chemical reaction presented in Eq. 4:

$$
\mathrm{CH}_{4}+2 \mathrm{O}_{2} \leftrightarrow \mathrm{CO}_{2}+2 \mathrm{H}_{2} \mathrm{O}
$$

from Eq. 4, one mole of methane gas requires the consumption of two moles of oxygen gas (demand for oxygen). Thus, one mole of methane equals $64 \mathrm{~g}$ of COD. Considering the normal conditions of temperature and pressure, the SMA can be presented as $\mathrm{g} \mathrm{COD} \mathrm{g}^{-1} \mathrm{VS} \mathrm{d}^{-1}[19]$.

\section{G. Physico-Chemical Analysis}

Samples of BR, BM and SM were analyzed for Organic Carbon (C) (Silva, 2009), Total Kjeldahl Nitrogen (N), total solids (TS) and volatile solids (VS) [20].

In order to evaluate the performance of the biodigestion process, SM was also analyzed as a function of the Chemical Oxygen Demand (COD) and RH were submitted to volatile solids analysis [20], [21].

The resulting sludge from Test 2 was analyzed in terms of the concentration of total solids (TS) and volatile solids (VS) [20] in order to aid in the interpretation of microbiological analysis. Results of the physico-chemical analysis and methane yield were presented as the average followed by the standard deviation.

\section{H. Qualitative Analysis of Organic Degrading Bacteria in the Sludges (Inocula)}

A qualitative analysis to identify the presence of bacteria able to degrade organic matter was performed using as reference the Colony Forming Units (CFU) method [22].

Methane yield from codigestion tests proposed in Table I, Test 2, was monitored and, as soon as it started decreasing (20 days), one of the duplicates was interrupted. A mixture (sludge + residual effluent) with a volume of $200 \mathrm{~mL}$ was kept in the biodigester and this mixture was homogenized and preserved at $39{ }^{\circ} \mathrm{C}$. The sludge from these tests was collected for microbiological analysis and for quantification of TS and VS.

From each sludge (IBR, IBM and ISM) a $1 \mathrm{~mL}$ aliquot was added to $9 \mathrm{~mL}$ of saline solution $\left(0.85 \mathrm{~g} \mathrm{~L}^{-1}\right)$. Then, from this first dilution $\left(10^{-1}\right)$ a series of dilutions of $10^{-2}, 10^{-4}, 10^{-6}, 10^{-8}$, $10^{-9}, 10^{-10}$ was prepared. For bacteria growth, samples of 1 $\mathrm{mL}$ of each dilution were transferred to Petri dishes, followed by addition of the specific culture medium, according to the 
plate method [22]. The samples were incubated in micro oxygenated medium at $35^{\circ} \mathrm{C}$, for 7 days.

Three culture media were used: 1) Digs medium, which was rich in nutrient to promote the growth of all types of bacteria, in less time of incubation [23]; 2) Lignolytic medium, which contained only lignin as carbon source, in order to favor the growth of lignin-degrading bacteria and 3) Cellulolytic medium that contained only cellulose as carbon source, in order to favor the growth of cellulose degrading bacteria [24]. This medium was followed by the screening for cellulase-producing microorganisms using Gram's iodine solution [25].

All medium had their $\mathrm{pH}$ adjusted to 6.5 and fungicide Cerconil ( $2 \mathrm{~mL}$ of a solution $0.1 \mathrm{~g} \mathrm{~L}^{-1}$ ) was added to them. The analyses were performed in duplicate and a control was done for each medium. After incubation, counts of bacterial colonies grown on the plates and CFU were estimated according to $\mathrm{Eq}$ 5. Petri dishes with 25-250 colonies were used as reference [22].

$$
C F U(m L)=\frac{C F U(\text { counted } \text { in the plate }) \cdot \text { dilution factor }}{\text { Aliquot }(m L)}
$$

\section{Influence of Bovine Excrement on Pilot-Scale Biodigester Startup}

Due to the results obtained in laboratory scale, the inocula obtained at the end of Test 1 was used in the pilot scale biodigesters, operating at batch regime. Two tests were performed in these biodigesters with a nominal capacity of 8 $\mathrm{L}$, constructed in PVC. They were fed with 7 liters of SM, $160 \mathrm{~g}$ of RH and $400 \mathrm{~mL}$ of inoculum. Biodigester A used the inoculum ISM and biodigester B used the inoculum IBM. The tests were conducted at $35{ }^{\circ} \mathrm{C}$ with intermittent stirring every 6 hours in order to provide homogenization of the system. The gas generated in this process was conducted to graduated gas meters after being washed with sodium hydroxide solution $\left(\mathrm{NaOH}: 3 \mathrm{~mol} \mathrm{~L}^{-1}\right)$. System performance was evaluated according to the generation of $\mathrm{CH}_{4}(\mathrm{~mL})$ in terms of VS ( $\mathrm{g}$ ) added.

\section{RESUlts E DisCUSSION}

\section{A. Inocula Preparation}

Swine and bovine manures and the ruminal content were submitted to physico-chemical analyses as soon as they were collected and the results are presented in Table II. It can be observed that SM has the lowest $\mathrm{C} / \mathrm{N}$ ratio, TS and VS contents.

Methane yield was used as an indicator of the development of the microorganisms necessaries for biodigestion and, consequently, the effective production of ISM, IBM and IBR inocula. Methane production was monitored daily and as the methane yield stabilized, the sludge was collected and stored for the next steps.

It was observed that there was a very large generation of methane for systems fortified with rumen content and bovine manure (Table III). These results are probably due to the great contribution of VS to the system and the improvement in the $\mathrm{C} / \mathrm{N}$ ratio, compared to the biodigestion of $\mathrm{SM}$ alone $[5]$.

TABLE II: RESULTS OF THE PHYSICO-CHEMICAL CHARACTERIZATION OF BR, BM AND SM

\begin{tabular}{llllll}
\hline \hline Inocula Source & $\mathrm{C}$ & $\mathrm{N}^{1}$ & $\mathrm{C} / \mathrm{N}$ & $\mathrm{TS}^{1}$ & $\mathrm{VS}^{2}$ \\
\hline Ruminal Content & $69 \pm 16$ & $1.8 \pm 0.1$ & 38 & $158 \pm 5$ & $96.2 \pm 1.0$ \\
Bovine Manure & $71 \pm 8$ & $3.2 \pm 0.6$ & 22 & $146 \pm 3$ & $92.3 \pm 1.3$ \\
Swine Manure & $16.7 \pm 0.6$ & $3.1 \pm 0.5$ & 5.4 & $50 \pm 2$ & $69.3 \pm 1.8$ \\
\hline \hline
\end{tabular}

where: $\mathrm{C}=$ Organic Carbon; $\mathrm{N}=$ Total Kjeldahl Nitrogen; TS: Total Solids; VS: Volatile Solids. ${ }^{1}$ Ruminal Content/ Bovine Manure: $\mathrm{g} \mathrm{kg}^{-1}$; Swine Manure: $\mathrm{g} \mathrm{L}^{-1}{ }^{2}{ }^{2} \mathrm{wt} \%$ on basis of the TS of sample.

TABLE III: RESULTS OF ACCUMULATED METHANE YIELD DURING INOCULA PREPARATION

\begin{tabular}{ll}
\hline \hline Inoculum & Accumulated $\mathrm{CH}_{4}(\mathrm{~mL})$ yield \\
\hline IBR (swine manure + ruminal content) & $5693 \pm 602$ \\
IBM (swine manure + bovine manure) & $8640 \pm 1206$ \\
ISM (swine manure) & $2556 \pm 192$ \\
\hline \hline
\end{tabular}

\section{B. Codigestion Test and Process Parameters}

To evaluate whether the inocula fortified with rumen microorganisms is able to improve methane production of $\mathrm{SM}$ with RH, a small portion of the IBR, IBM and ISM inocula were used in the BMP and SMA tests. Each one of these inocula (sludge from the biodigestion process) was used in order to minimize the positive contribution of the chemical composition of $\mathrm{BR}$ and $\mathrm{BM}$, especially the $\mathrm{C} / \mathrm{N}$ ratio, as detected in 3.1. Controls with only inocula were used to determine biogas production, but the results were negligible (production $<1 \%$ of total volume) and were not presented. The parameters used to perform BMP and SMA tests, as well as their respective results, are shown in Table IV. The amount of sludge $(\mathrm{mL})$ added to each biodigester to obtain 2 to $5 \mathrm{~g}$ VS of biomass was estimated according to the concentration of VS present therein. The amount of VS added to each biodigester corresponded to the sum of the inoculum, rice husk and swine manure contributions and was called VST. The COD measured in the SM was considered as the initial biodigestion value (COD). For example, the codigestion carried out in Test $1, \mathrm{BR} 1$, used $100 \mathrm{~mL}$ of sludge, $12 \mathrm{~g}$ of RH and $600 \mathrm{~mL}$ of SM, totalizing: $20.5 \mathrm{~g} \mathrm{~L}^{-1}$ $\mathrm{VS}_{\mathrm{T}} ; 12.7 \mathrm{~g} \mathrm{~L}^{-1}$ of $\mathrm{COD}_{\mathrm{i}}$ and $2 \mathrm{~g}$ of biomass ( $\mathrm{g}$ of VS from sludge).

From Table IV, Test 1, it can be observed the accumulated volume of methane yield was higher for BR1 $(4086 \mathrm{~mL})$. The worst result was for the biodigestion using inoculum ISM, produced only with swine manure $(1847 \mathrm{~mL})$. The results of $\mathrm{CH}_{4 \mathrm{spV}}$ were low for all biodigesters, when compared to the literature data. The production of methane, due to the biodigestion of only swine manure, is around $350 \mathrm{~mL}$ of $\mathrm{CH}_{4}$ $\mathrm{g}^{-1} \mathrm{VS}_{\mathrm{ad}}$ [26]-[29]. These results demonstrate the lack of maturity of the inoculum used, especially in SM1 test, which presented very low values of efficiency $(E=40.2 \%)$ and SMA (0.09).

Test 2 was performed following the same criteria of Test 1. However, there was an increase in the VST concentration and in the $\mathrm{COD}_{\mathrm{i}}$ due to the characteristics of effluent sampled and used in the biodigestion. Part of the sludge produced in Test 1 was collected and used as inoculum in Test 2 in order to continue the evaluation of the influence of IBR, IBM and 
ISM.

TABLE IV: PARAMETERS AND RESULTS USED TO PERFORM THE BMP AND SMA ASSAY

\begin{tabular}{|c|c|c|c|c|c|c|}
\hline & \multicolumn{3}{|c|}{$\begin{array}{l}\text { Test } 1 \\
\end{array}$} & \multicolumn{3}{|c|}{ Test 2} \\
\hline & BR1 & BM1 & SM1 & BR2 & BM2 & SM2 \\
\hline VS IN (g/L) & $\begin{array}{l}20.0 \pm \\
1.5\end{array}$ & $\begin{array}{l}63.5 \pm \\
6.10\end{array}$ & $\begin{array}{l}64.0 \pm \\
2.4\end{array}$ & $\begin{array}{l}74.4 \pm \\
0.3\end{array}$ & $\begin{array}{l}87.0 \pm \\
0.4\end{array}$ & $\begin{array}{l}86.1 \pm \\
2.9\end{array}$ \\
\hline $\begin{array}{l}\text { VS SM } \\
(\mathrm{g} / \mathrm{L})\end{array}$ & $\begin{array}{l}16.0 \pm \\
1.1\end{array}$ & $\begin{array}{l}16.0 \pm \\
1.1\end{array}$ & $\begin{array}{l}16.0 \pm \\
1.1\end{array}$ & $\begin{array}{l}21.0 \pm \\
1.2\end{array}$ & $\begin{array}{l}21.0 \pm \\
1.2\end{array}$ & $\begin{array}{l}21.0 \pm \\
1.2\end{array}$ \\
\hline $\begin{array}{l}\text { VS RH } \\
\text { (wt } \%)\end{array}$ & $\begin{array}{l}74.08 \\
\pm 0.63\end{array}$ & $\begin{array}{l}74.08 \\
\pm 0.63\end{array}$ & $\begin{array}{l}74.08 \pm \\
0.63\end{array}$ & $\begin{array}{l}74.08 \\
\pm 0.63\end{array}$ & $\begin{array}{l}74.08 \pm \\
0.63\end{array}$ & $\begin{array}{l}74.08 \\
\pm 0.63\end{array}$ \\
\hline $\begin{array}{l}\text { Volume IN } \\
(\mathrm{mL})\end{array}$ & 100 & 30 & 30 & 60 & 50 & 50 \\
\hline $\begin{array}{l}\text { Volume SM } \\
(\mathrm{mL})\end{array}$ & 600 & 600 & 600 & 600 & 600 & 600 \\
\hline Mass RH (g) & 12 & 12 & 12 & 12 & 12 & 12 \\
\hline $\operatorname{VST}(\mathrm{g} / \mathrm{L})$ & 20.5 & 20.4 & 20.4 & 26.0 & 25.9 & 25.8 \\
\hline $\mathrm{COD}_{\mathrm{i}}(\mathrm{g} / \mathrm{L})$ & $\begin{array}{l}12.7 \pm \\
3.6\end{array}$ & $\begin{array}{l}12.7 \pm \\
3.6\end{array}$ & $\begin{array}{l}12.7 \pm \\
3.6\end{array}$ & $\begin{array}{l}59.6 \pm \\
6.2\end{array}$ & $\begin{array}{l}59.6 \pm \\
6.2\end{array}$ & $\begin{array}{l}59.6 \pm \\
6.2\end{array}$ \\
\hline $\begin{array}{l}\text { Biomassa (g } \\
\text { VS) }\end{array}$ & $\approx 2.0$ & $\approx 2.0$ & $\approx 2.0$ & $\approx 4.5$ & $\approx 4.5$ & $\approx 4.5$ \\
\hline $\mathrm{CH}_{4 \mathrm{tV}}(\mathrm{mL})$ & $\begin{array}{l}4086 \\
\pm 71\end{array}$ & $\begin{array}{l}3714 \\
\pm 343\end{array}$ & $\begin{array}{l}1847 \pm \\
44\end{array}$ & 6386 & 7457 & 7183 \\
\hline $\begin{array}{l}\mathrm{CH}_{4 \mathrm{spV}} \\
(\mathrm{mL} / \mathrm{g})\end{array}$ & 199.3 & 182.1 & 90.5 & 246 & 288 & 278 \\
\hline $\begin{array}{l}\mathrm{CH}_{4} \text { theo } \\
(\mathrm{mL})\end{array}$ & 4594 & 4594 & 4594 & 15717 & 15717 & 15717 \\
\hline $\begin{array}{l}\text { Efficiency } \\
\text { (E) }\end{array}$ & 88.9 & 80.8 & 40.2 & 40.6 & 47.4 & 45.7 \\
\hline SMA & 0.32 & 0.29 & 0.09 & 0.34 & 0.33 & 0.30 \\
\hline
\end{tabular}

where, IN: inoculum; SM: swine manure; RH: rice husk, VS: volatile solids; VST: total VS, $\mathrm{COD}_{\mathrm{i}} ;$ : COD measured in the $\mathrm{SM} ; \mathrm{CH}_{4 \mathrm{tv}}$ : total volume produced; $\mathrm{CH}_{4}{ }_{\mathrm{spv}}$ : specific yield; $\mathrm{CH}_{4}$ theo; theoretical value of $\mathrm{CH}_{4}$ production; SMA: Specific Methanogenic Activity $\left(\mathrm{mL} \mathrm{CH}_{4} \mathrm{~g}^{-1} \mathrm{VS} \mathrm{d}^{-1}\right)$.

The values of $\mathrm{CH}_{4} \mathrm{tv}$ and $\mathrm{CH}_{4} \mathrm{spV}$ increased in Test 2, compared to Test 1 for all inocula evaluated. These results may be due to the increase in the availability of organic matter, as can be seen by the increase of COD and VST and also by the improvement in the maturity of the inocula used. For Test 2, the SMA values for the BR2, BM2 and SM2 are very close $(0.34,0.33,0.30$ respectively) differently from Test 1 . It is known that the results of SMA are very dependent on operational conditions, such as the type/concentration of substrate used [16], [17]. However, the values and the behavior of SMA in Test 1 and 2 are consistent with the literature. Zeeuw and Lettinga [30] reported an increase of 0.04 to $0.75 \mathrm{~g} \mathrm{COD} \mathrm{g}^{-1} \mathrm{VSS} \mathrm{d}^{-1}$ for low quality sludge submitted to a biodigestion in nutrient mixture for 6 weeks.

Results from $\mathrm{CH}_{4 \mathrm{spV}}$ are closer to values found in the literature (around $400 \mathrm{~mL}$ of $\mathrm{CH}_{4} \mathrm{~g} \mathrm{VS}_{\mathrm{ad}}$ ). It is interesting to note that even with reduced efficiency, there was an evolution from Test 1 to Test 2 and all biodigestion tests show similar results regardless of the inoculums used.

Fig. 1 ( $a$ and b) shows the cumulative methane volume curve as a function of time, taken as the monitoring days for Test 1 and 2. From this curve it is possible to verify that the use of the fortified inoculum favored the production of methane during Test 1 . It is an indication that the microbial consortium was improved with the addition of BR or BM for a shorter biodigestion time and a richer effluent of lignocellulosic material.

However, it was observed that the methane generation has little difference between the biodigesters treated with the different inocula in the Test 2. Cordoba et al. [31] could not identify improvements in the monodigestion of swine manure inoculated with ruminal content compared to others inocula, for a biodigestion period of 140 days. Albeit, it was observed that in the first 20 days of biodigestion, the effluent inoculated with ruminal content had the highest daily production of methane, with a very significant difference [31].

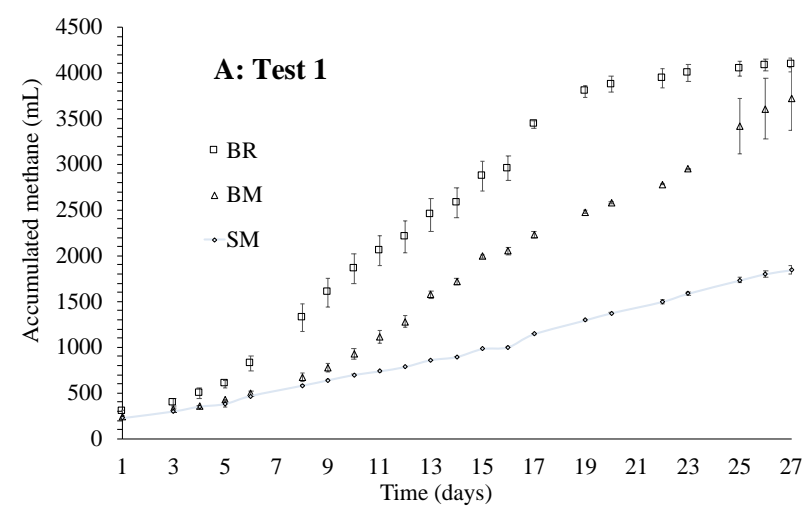

(a)

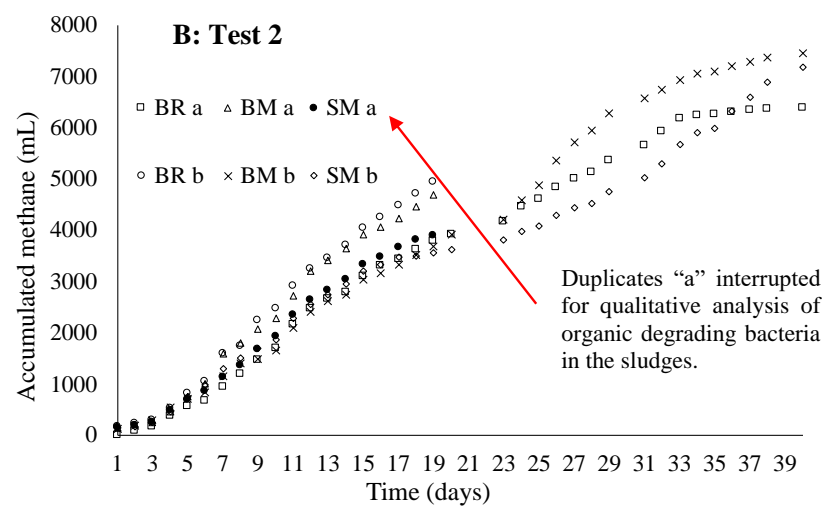

(b)

Fig. 1. Accumulated methane yield (mL) for codigestion Test 1(a) and Test 2 (b).

These results are consistent with those obtained in Tests 1 and 2. The contribution of organic matter concentration from $\mathrm{SM}$ is greater in Test 2 than in Test 1 and Test 2 is more similar to the monodigestion performed by Córdoba et al. [31]. This factor may have contributed to a better adaptation of the microorganisms from the SM to the biodigestion medium.

\section{Quantitative Analysis of Organic Degrading Bacteria in the Sluges (Inocula)}

Plates filled with Digs medium showed a large growth of bacteria. At dilutions below $10^{-10}$ the growth provided the formation of a bacterial film on the plates. At the $10^{-10}$ dilution it was possible to identify the colonies separately, although they were present in large numbers $(>250)$. For Digs medium, it was observed colonies of different morphotypes. The formation of many small colonies inside the agar can be attributed to presence of facultative anaerobic bacterias or microaerophiles ones. Some colonies of larger diameter, above the agar, are probably formed by facultative anaerobic bacteria. Fig. 2A shows the growth pattern of the colonies, for the three investigated inocula, in the Digs medium.

In the lignolytic medium, bacterial growth was low for all inocula: around 10 to 40 colonies, for the $10^{-2}$ dilution. It must be highlighted that the medium rich in lignin is very 
dark, which made it difficult to identify bacteria growth.

The cellulolytic medium showed a great growth of colonies. After the application of the iodine solution, the control acquired the characteristic blue-black coloration of the complex formed between the cellulose and the solution. The plates with smaller dilutions presented very clear zones in contrast with the dark zones, suggesting that there was a large area affected by cellulase and consequently a great bacteria growth. At $10^{-10}$ dilution (Fig. 2B), small hallos (clear spots) could be identified and allowed the bacterial colonies to be distinguished (around 40 units per plate).
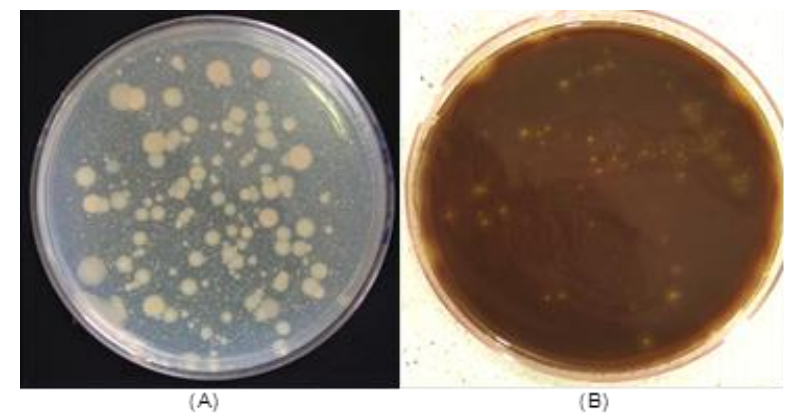

(B)

Fig. 2. Colony growth pattern, for the three inocula investigated in $A$ ) the Digs medium, dilution of $10^{-10}$ and B) cellulolytic medium $10^{-10}$.

It was observed that the plates followed the same pattern of bacteria growth, for the three inocula investigated. When evaluating growth in the Digs medium, it can be stated that there is a very large bacterial community, much more than $250 \cdot 10^{10}$ million CFU per $\mathrm{mL}$ of sample. The amount of cellulose degrading bacteria is also very significant, in the order of $40 \cdot 10^{10}$ million CFU per $\mathrm{mL}$ of sample. Lignin degrading agents are also present, but in smaller quantities, around $10^{2}$ million CFU per $\mathrm{mL}$ of sample. The similarity in the quantification of the bacterial community in the three analyzed inocula (Table V), as well as the similarity of the SMA values in Test 2, can explain the methane generation results after 20 days of biodigestion as shown in Fig. 1 b.

\section{Influence of Bovine Excrement on Pilot-Scale Biodigestor Startup}

The pilot scale biodigesters test used ISM and IBM inocula. The choice was based on the good results of the IBM inoculum and also due to the greater availability and easy handling of bovine manure, which will favor further test or its use on a larger scale. Fig. 3 shows that biodigester (B), where IBM sludge was used, presented a generation of methane consistent with the laboratory scale results. However, biodigester (A), which used ISM sludge, did not have satisfactory results for methane generation.

One of the main problems of the biodigestion is to enhance the startup of the process that many times use a very poor quality digested sewage sludge as seed material. [30]. Even more, according to these authors it is possible to cultivate a highly active biomass within a period of 6 weeks. However, in order to achieve this, the initial loading rate should not appreciably exceed the specific activity of the seed sludge to prevent an inhibition of the microorganisms adaptation to the new substrate [16], [30]. According to SMA data for the sludge from BM1 and SM1 tests: 0.29 and $0.09 \mathrm{~g} \mathrm{COD/g} \mathrm{VS}$ $\mathrm{d}^{-1}$, respectively, and considering the high organic load applied to the system $\left(\mathrm{COD}=59.6 \mathrm{~g} \mathrm{~L}^{-1}\right)$, it can be stated that the quantity/quality of the sludge added to biodigester A was not sufficient for the anaerobic treatment of the effluent. Probably, on a laboratory scale, the use of sludge from test SM1 led to satisfactory results due to the better homogenization that a smaller scale system allows (greater dilution of volatile organic matter and less impact on the $\mathrm{pH}$ of the system).

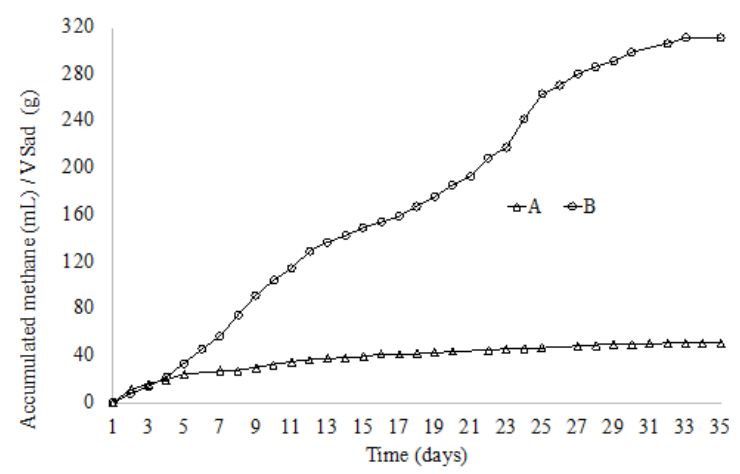

Fig. 3. Accumulated methane yield, as a function of the $\mathrm{VS}_{\mathrm{ad}}$, for the biodigesters operating with the inoculum obtained only with swine effluent (A) and fortified with bovine excrement (B).

TABLE V: TOTAL SOLIDS (TS) AND VOLATILE SOLIDS (VS) CONTENT FOR THE INOCULA SUBMITTED TO QUALITATIVE ANALYSIS OF ORGANIC DEGRAdING BACTERIA AND THEIR RESPECTIVE ORDER OF MAGNITUdE OF CFU, PER GRAM OF SLUDGE ADDED

\begin{tabular}{llllll}
\hline Inoculum & $\begin{array}{l}\mathrm{TS}(\mathrm{g} \\
\left.\mathrm{L}^{-1}\right)\end{array}$ & $\begin{array}{l}\mathrm{VS}(\mathrm{g} \\
\left.\mathrm{L}^{-1}\right)\end{array}$ & $\begin{array}{l}\text { Total } \\
\text { bacteria } \\
(\mathrm{CFU} / \mathrm{g} \\
\text { sludge })\end{array}$ & $\begin{array}{l}\text { Lignolytic } \\
\text { bacteria } \\
(\mathrm{CFU} / \mathrm{g} \\
\text { sludge })\end{array}$ & $\begin{array}{l}\text { Cellulolytic } \\
\text { bacteria } \\
(\mathrm{CFU} / \mathrm{g} \\
\text { sludge })\end{array}$ \\
\hline IBR & $99.5 \pm$ & $74.4 \pm$ & $>2.5 \cdot$ & $1.0 \cdot 10^{3}$ & $4.0 \cdot 10^{12}$ \\
& 2.3 & 0.4 & $10^{13}$ & & \\
IBM & $111.2 \pm$ & $87.0 \pm$ & $>2.2 \cdot$ & $0.9 \cdot 10^{3}$ & $3.6 \cdot 10^{12}$ \\
& 2.6 & 0.4 & $10^{13}$ & & \\
ISM & $112.8 \pm$ & $86.1 \pm$ & $>2.2 \cdot$ & $0.9 \cdot 10^{3}$ & $3.5 \cdot 10^{12}$ \\
& 4.4 & 2.9 & $10^{13}$ & & \\
\hline \hline
\end{tabular}

\section{CONCLUSION}

The use of microorganisms from the bovine rumen improved the codigestion tests, mainly at the beginning of the process. In the course of time, the fortified inoculum lowers the influence on process performance, since the quantity and characteristics of organic degrading bacteria appears similar on the three inocula. On pilot scale, the use of bovine manure presented a relevant performance on methane yield. Due to the results presented and the availability of the bovine manure, it can be considered a relevant inoculum to be used in the startup of codigestion of swine manure and lignocellulosic residues, as rice husk.

\section{CONFLICT OF INTEREST}

The authors declare no conflict of interest.

\section{AUTHOR CONTRIBUTIONS}

B. S. Leite and S. A. F. Leite performed codigestion test and physico-chemical analysis. A. T. P. dell'Isola and S. A. F. Leite performed inocula preparations and characterization. S. A. F. Leite and J. V. H. d'Angelo writing and reviewing the paper; all authors had approved the final version. 


\section{ACKNOWLEDGMENT}

The authors thanks Universidade Federal de Viçosa (UFV), Universidade Federal de Campinas (Unicamp), Fundação de Amparo à Pesquisa de Minas Gerais -FAPEMIG, Fundação de Amparo à Pesquisa do Estado de São Paulo (FAPESP) and Conselho Nacional de Desenvolvimento Científico e Tecnológico - CNPQ.

\section{REFERENCES}

[1] T. Forster-Carneiro, M. D. Berni, I. L. Dorileo, and M. A. Rostagno, "Biorefinery study of availability of agriculture residues and wastes for integrated biorefineries in Brazil," Resour. Conserv. Recycl., vol. 77, pp. 78-88, 2013.

[2] J. Mata-Alvarez, J. Dosta, M. S. Romero-Güiza, X. Fonoll, M. Peces, and S. Astals, "A critical review on anaerobic co-digestion achievements between 2010 and 2013," Renew. Sustain. Energy Rev., vol. 36, pp. 412-427, 2014.

[3] R. Chandra, H. Takeuchi, and T. Hasegawa, "Methane production from lignocellulosic agricultural crop wastes: A review in context to second generation of biofuel production," Renewable and Sustainable Energy Reviews, vol. 16, no. 3, pp. 1462-1476, 2012.

[4] Z. B. Yue, W. W. Li, and H. Q. Yu, "Application of rumen microorganisms for anaerobic bioconversion of lignocellulosic biomass," Bioresource Technology, vol. 128, pp. 738-744, 2013.

[5] D. R. S. Lima, O. F. H. Adarme, B. E. L. Baêta, L. V. A. Gurgel, and S. F. Aquino, "Influence of different thermal pretreatments and inoculum selection on the biomethanation of sugarcane bagasse by solid-state anaerobic digestion: A kinetic analysis," Ind. Crops Prod., vol. 111, no. May, pp. 684-693, 2018.

[6] D. M. Wall et al., "Investigation of effect of particle size and rumen fluid addition on specific methane yields of high lignocellulose grass silage," Bioresour. Technol., vol. 192, pp. 266-271, Sep. 2015.

[7] B. H. Yan, A. Selvam, and J. W. C. Wong, "Application of rumen microbes to enhance food waste hydrolysis in acidogenic leach-bed reactors," Bioresour. Technol., vol. 168, pp. 64-71, Sep. 2014.

[8] T. T. Berchielli, A. V. Pires, and S. G. Oliveira, Nutrição de Ruminantes, 2nd ed. Jaboticabal: Funep, 2011.

[9] P. J. Weimer, J. B. Russell, and R. E. Muck, "Lessons from the cow: What the ruminant animal can teach us about consolidated bioprocessing of cellulosic biomass," Bioresour. Technol., vol. 100, no. 21, pp. 5323-5331, 2009.

[10] B. Budiyono, I. N. Widiasa, S. Johari, and S. Sunarso, "Increasing biogas production rate from cattle manure using rumen fluid as inoculums," Int. J. Sci. Eng., vol. 6, no. 1, pp. 31-38, 2014.

[11] O. C. Okeh, C. O. Onwosi, and F. J. C. Odibo, "Biogas production from rice husks generated from various rice mills in Ebonyi State, Nigeria," Renew Energy, vol. 62, pp. 204-208, 2014.

[12] S. Y. Kim, P. Pramanik, P. L. E. Bodelier, and P. J. Kim, "Cattle manure enhances methanogens diversity and methane emissions compared to swine manure under rice paddy," PLoS One, vol. 9, no. 12 , pp. 1-18, 2014.

[13] E. B. Gueguim Kana, J. K. Oloke, A. Lateef, and M. O. Adesiyan, "Modeling and optimization of biogas production on saw dust and other co-substrates using Artificial Neural network and Genetic Algorithm," Renew Energy, vol. 46, pp. 276-281, 2012.

[14] W. S. Lopes, V. D. Leite, and S. Prasad, "Influence of inoculum on performance of anaerobic reactors for treating municipal solid waste," Bioresour. Technol., vol. 94, no. 3, pp. 261-266, 2004.

[15] S. M. Bertolino and C. F. Carvalho, "Caracterização e biodegradabilidade aeróbia e anaeróbia dos esgotos produzidos em Campus universitário," Eng. Sanitária e Ambient., vol. 13, no. 3, pp. 271-277, 2008.

[16] A. Hussain and S. K. Dubey, "Specific methanogenic activity test for anaerobic treatment of phenolic wastewater," Appl. Water Sci., vol. 52 , no. 37-39, pp. 7015-7025, 2014.

[17] S. F. Aquino, C. A. L. Chernicharo, E. Foresti, M. D. L. F. Dos Santos, and L. O. Monteggia, "Metodologias para determinação da atividade metanogênica específica (AME) em lodos anaeróbios," Eng. Sanit. e Ambient., vol. 12, no. 2, pp. 192-201, 2007.

[18] D. Li et al., "Effects of feedstock ratio and organic loading rate on the anaerobic mesophilic co-digestion of rice straw and cow manure," Bioresour. Technol., vol. 189, pp. 319-326, 2015.

[19] C. A. L. Chernicharo, Reatores Anaeróbios, Belo Horizonte: Departamento de Engenharia Sanitária e Ambiental-UFMG, 2007.
[20] American Public Health Association (APHA), American Water Works Association (AWWA), and Water Environment Federation (WEF), Standard Methods for the Examination of Water and Wastewater, Washington, DC, 1998.

[21] G. Rendeiro and M. Nogueira, Combustão e Gasificação de Biomassa Sólida: Soluções Energéticas para a Amazônia, Brasília, 2008.

[22] G. J. Tortora, B. Funke, and C. L. Cae, Microbiologia, 10th ed. Porto Alegre: ARTMED, 2012.

[23] D. Johana, V. O. Andrade, and V. L. D. Baldani, Protocolos Para Preparo de Meios de Cultura da Embrapa Agrobiologia, Seropédica, 1999.

[24] J. A. R. Lozada, "Prospecção de bactérias do lodo de esgoto de abatedouro de aves com potencial degradador de substâncias orgânicas e promotor do crescimento de plantas," Universidade Federal Viçosa, 2015.

[25] R. C. Kasana, R. Salwan, H. Dhar, S. Dutt, and A. Gulati, “A rapid and easy method for the detection of microbial cellulases on agar plates using Gram's iodine," Curr. Microbiol., vol. 57, no. 5, pp. 503-507, 2008.

[26] M. J. Cuetos, C. Fernández, X. Gómez, and A. Morán, “Anaerobic co-digestion of swine manure with energy crop residues," Biotechnol. Bioprocess Eng., vol. 16, no. 5, pp. 1044-1052, 2011.

[27] H. B. Møller, S. G. Sommer, and B. K. Ahring, "Methane productivity of manure, straw and solid fractions of manure," Biomass and Bioenergy, vol. 26, no. 5, pp. 485-495, May 2004.

[28] P. Panichnumsin, A. Nopharatana, B. Ahring, and P. Chaiprasert, "Production of methane by co-digestion of cassava pulp with various concentrations of pig manure," Biomass and Bioenergy, vol. 34 , no. 8 , pp. 1117-1124, 2010.

[29] J. Ye et al., "Improved biogas production from rice straw by co-digestion with kitchen waste and pig manure," Waste Manag., vol. 33, no. 12, pp. 2653-2658, 2013.

[30] W. de Zeeuw and G. Lettinga, "Acclimation of digested sewage sludge during start-up of an upflow anaerobic sludge blanket (UASB) reactor," in Proc. the 35th Industrial Waste Conference, 1980, pp. 39-47.

[31] V. Córdoba, M. Fernández, and E. Santalla, "The effect of different inoculums on anaerobic digestion of swine wastewater," J. Environ. Chem. Eng., vol. 4, no. 1, pp. 115-122, Mar. 2016.

Copyright (C) 2019 by the authors. This is an open access article distributed under the Creative Commons Attribution License which permits unrestricted use, distribution, and reproduction in any medium, provided the original work is properly cited (CC BY 4.0).

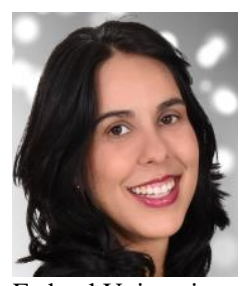

Leite S. A. F was born in Brazil in 1982. She got the Ph.D. in chemical engineering from the State University of Campinas; the master in chemical engineering, Federal University of Minas Gerais (UFMG), specialist in environmental education, SENAC-MG and chemistry graduate, also by UFMG. Since 2009, she has worked as professor of the environmental technology management at the Federal University of Viçosa, Campus Florestal (UFV- Campus Florestal).

She works at the university develops extension and research activities, which stand out as leaders focused on the evaluation of performance in water systems, the work solution and the treatment and valorization of the biomass generated in agricultural processes.

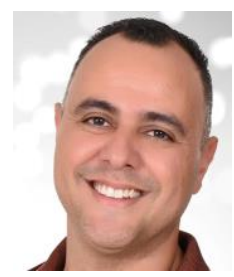

Leite B. S. was born in Brazil in 1981. He graduated in industrial chemistry from the Vale do Rio Doce University - UNIVALE in 2002, in the year of 2008 he obtained a master's degree in chemical engineering from the Federal University of Minas Gerias - UFMG, in 2012 he obtained the title of $\mathrm{PhD}$ in chemical engineering from the State University of Campinas.

Since 2010, he has worked as professor at the Federal University of Viçosa, Campus Florestal (UFV- Campus Florestal) He has experience in Chemistry, with emphasis on chemical physics, working in the area of chemical and computer processes and in the mining and pulp and paper production sector. He is currently developing his research in agroindustrial waste use with the objective of producing new materials and energy. 
Dell'Isola A. T. P was born in Brazil in 1968. She holds a degree in veterinary medicine from the Federal University of Minas Gerais (1991), a master's degree in animal science from the Federal University of Minas Gerais (1995), a PhD in animal science from the Federal University of Minas Gerais (2001) and a $\mathrm{PhD}$ in zootechnics (2012).

Since 1992, she has professor at the Federal University of Viçosa Campus de Florestal, working mainly in the following subjects: pork and poultry production, meat processing. She has been an instructor of SENAR MG since 1997 and works in the PNDS.

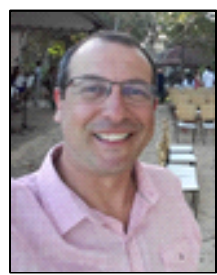

d'Angelo J. V. H. was born in Brazil in 1969. He graduated in chemical engineering from the Federal University of Minas Gerais (1990), the master's degree in chemical engineering from the University of Campinas (1994), the PhD in chemical engineering from the University of Campinas (1998) and associate professor in the area of the Chemical Processes (2012).

Since 2002, he has been a full-time professor at the
Department of Chemical Systems Engineering, School of Chemical Engineering, University of Campinas, currently at level MS-5.2 (associate professor II). He has worked professionally in the area of the chemical processes in the pulp and paper industry and consulting in energy projects. In the administrative area of the Unicamp he has held the positions of Head of Department, Undergraduate Coordinator and Advisor to the Graduate Rectorate. He is currently developing research in the area of the analysis and optimization of thermodynamic cycles (power and refrigeration) and optimization of pulp and paper production processes. 